\title{
Hubungan Derajat Asidosis dengan Kadar Ureum dan Kreatinin Bayi Asfiksia
}

\author{
Heru Muryawan, Adhie Nur Radityo \\ Bagian Ilmu Kesehatan Anak Fakultas Kedokteran Universitas Diponegoro/RSUP Dr.Kariadi, Semarang
}

Latar belakang. Asfiksia neonatorum merupakan masalah kesehatan pada bayi baru lahir yang dapat menyebabkan asidosis. Selanjutnya asidosis metabolik menjadi salah satu penyebab gangguan metabolisme sel, ditandai dengan penurunan $\mathrm{pH}, \mathrm{pO}_{2}$, base excess, dan peningkatan $\mathrm{pCO}_{2}$. Parameter tersebut dapat digunakan untuk mengetahui keadaan hipoksia pada bayi. Salah satu gangguan fungsi organ adalah penurunan fungsi ginjal yang ditandai dengan peningkatan ureum dan kreatinin.

Tujuan. Membuktikan hubungan antara derajat asidosis metabolik pada bayi asfiksia dengan peningkatan kadar ureum dan kreatinin.

Metode. Penelitian kohort prospektif pada bayi baru lahir dengan asfiksia di RSUP Dr. Kariadi Semarang bulan Januari-Desember 2010. Derajat asidosis ditentukan berdasarkan kadar $\mathrm{pH}$ dan base excess (BE); $\mathrm{pH}$ 7,2-7,29 asidosis ringan, sedangkan $\mathrm{pH}<7,2$ asidosis berat. Penilaian ureum dan kreatinin dilakukan pada hari keempat kehidupan. Terjadi peningkatan kadar ureum dan kreatinin apabila kadar ureum $>20 \mathrm{mg} / \mathrm{dL}$, kreatinin $>1 \mathrm{mg} /$ dL. Data dianalisis dengan uji chi-square, tingkat kemaknaan secara statistik, apabila $p \leq 0,05$.

Hasil. Subjek 63 neonatus, 32 menderita asidosis berat, dan 31 asidosis ringan. Neonatus dengan asidosis berat pada hari keempat rerata kadar ureum 26,69 $( \pm 11,8) \mathrm{mg} / \mathrm{dL}$ dibanding kelompok asidosis ringan 27,06 $( \pm 12,9) \mathrm{mg} / \mathrm{dL}, \mathrm{p}=0,14$. Kreatinin kelompok asidosis berat $1,09( \pm 0,5) \mathrm{mg} / \mathrm{dL}$ berbeda bermakna $(\mathrm{p}=0,03)$ dibandingkan kreatinin pada kelompok asidosis ringan $0,89( \pm 0,5) \mathrm{mg} / \mathrm{dL}$. Tidak terdapat hubungan yang bermakna antara derajat asidosis dengan peningkatan kadar ureum $(\mathrm{p}=0,87)$ dan kreatinin $(\mathrm{p}=0,08)$ pada hari keempat kehidupan.

Kesimpulan. Derajat asidosis tidak berhubungan dengan peningkatan kadar ureum dan kreatinin pada neonatus usia empat hari. Sari Pediatri 2011;13(4):239-43.

Kata kunci: asfiksia, asidosis metabolik, ureum, dan kreatinin

\footnotetext{
Alamat korespondensi:

Dr. M. Heru Muryawan Sp A. Bagian IKA FK UNDIP / RS Dr. Kariadi, Jl. Dr. Sutomo 16 - 18 Semarang Telp / Fax $024-8414296$ HP : 081 325641 808. Email : herumurya@yahoo.com
}

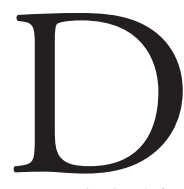
alam dua dekade terakhir teknik monitor pada bayi ante dan intra partum berkembang pesat, namun risiko asfiksia pada bayi baru lahir tetap menjadi masalah. ${ }^{1,2}$ Asfiksia neonatorum merupakan salah satu problem kesehatan pada bayi baru lahir yang 
dapat menyebabkan hipoksemia, hiperkapnia, dan asidosis yang jika tidak ditangani dengan baik dapat menyebabkan gangguan fungsi organ. ${ }^{3-9}$ Selain hipoksia yang dapat menyebabkan kerusakan pada sel, keadaan asidosis metabolik juga merupakan salah satu penyebab gangguan pada metabolisme sel dan keadaan asidosis juga merupakan indikator hipoksia. ${ }^{2}$

Analisis gas darah pada bayi asfiksia akan menunjukkan gambaran hipoksemia, hiperkapnia dan asidosis yang ditandai dengan penurunan $\mathrm{pH}$, $\mathrm{pO}_{2}$, base excess dan peningkatan $\mathrm{pCO}_{2}$. Parameter tersebut dapat digunakan untuk mengetahui keadaan hipoksia pada bayi. Salah satu gangguan fungsi organ adalah penurunan fungsi ginjal yang ditandai dengan peningkatan kadar ureum dan kreatinin. ${ }^{10}$

Penelitian bertujuan mengetahui hubungan antara derajat asidosis metabolik pada bayi asfiksia dengan peningkatan kadar ureum dan kreatinin.

\section{Metode}

Penelitian kohort prospektif yang dilakukan di bangsal perawatan bayi risiko tinggi (PBRT) dan neonatal intensive care unit (NICU) Bagian Ilmu Kesehatan Anak FK Undip/RSUP dr. Kariadi Semarang, sejak Januari 2010 sampai dengan Desember 2010. Subyek penelitian adalah bayi baru lahir yang mengalami asfiskia dengan kehamilan cukup bulan, berat lahir sesuai masa kehamilan, tidak menderita kelainan kongenital, diuresis cukup dalam 24 jam pertama, dan orang tua bersedia mengisi formulir persetujuan. Kriteria asfiksia ditentukan dengan nilai APGAR pada menit pertama dan kelima kurang dari tujuh disertai dengan hasil analisa gas darah, yang diambil segera setelah persalinan sebelum mendapat oksigen dan cairan paling lama 30 menit setelah lahir, $\mathrm{pH}<7,3$; base excess $-9 \pm 4$. Untuk derajat asidosis ditentukan berdasarkan kadar $\mathrm{pH}$ yaitu $\mathrm{pH}$ 7,2-7,29 asidosis ringan sedangkan $\mathrm{pH}<7,2$ asidosis berat. ${ }^{11}$

Penilaian ureum dan kreatinin dilakukan pada hari keempat pasca persalinan agar tidak terpengaruh kadar ureum dan kreatinin ibu. Peningkatan kadar ureum dan kreatinin apabila kadar ureum $>20 \mathrm{mg} /$ $\mathrm{dL}$, kreatinin $>1 \mathrm{mg} / \mathrm{dL}$.

Data dianalisis dengan uji Chi-square dengan tingkat kemaknaan $\mathrm{p} \leq 0,05$ dan interval kepercayaan 95\% (IK 95\%).

\section{Hasil}

Selama periode Januari 2010 sampai dengan Desember 2010 didapatkan 77 neonatus yang memenuhi kriteria inklusi, 7 orang tua/wali menolak mengikuti penelitian dan 7 neonatus meninggal selama pemantauan. Total subyek penelitian adalah 63 neonatus dengan asfiksia, terdiri dari 32 neonatus dengan asidosis berat dan 31 neonatus asidosis ringan. Karakteristik neonatus tertera pada Tabel 1 .

Tabel 1 menunjukkan tidak ada perbedaan dalam berat lahir dan jenis kelamin antara bayi asfiksia dengan derajat asidosis. Kadar $\mathrm{pH}$ antara kelompok asidosis berat dan sedang berbeda bermakna secara statistik.

Tabel 1. Karakteristik subjek

\begin{tabular}{|c|c|c|c|}
\hline Karakteristik & $\begin{array}{c}\text { Kelompok } \\
\text { asidosis berat } \\
(\mathrm{n}=32)\end{array}$ & $\begin{array}{c}\text { Kelompok } \\
\text { asidosis ringan } \\
(\mathrm{n}=31)\end{array}$ & $p$ \\
\hline Berat lahir (gram, rerata, SB) & $2.898 \pm 365,6$ & $3.032 \pm 354,5$ & $0,3^{*}$ \\
\hline \multicolumn{4}{|l|}{ Jenis kelamin bayi (n, \%) } \\
\hline - Laki-laki & $14(44)$ & $15(48)$ & \\
\hline - Perempuan & $18(56)$ & $16(52)$ & $0,7^{£}$ \\
\hline \multicolumn{4}{|l|}{ Analis gas darah (rerata, SB) } \\
\hline - $\mathrm{pH}$ & $7,09 \pm 0,1$ & $7,24 \pm 0,4$ & $0,007^{*}$ \\
\hline - $\mathrm{pO} 2(\mathrm{mmHg})$ & $177,22 \pm 77,14$ & $181,94 \pm 70,61$ & $0,8^{\S}$ \\
\hline - $\mathrm{pCO} 2(\mathrm{mmHg})$ & $26,84 \pm 9,73$ & $24,68 \pm 6,38$ & $0,3^{\S}$ \\
\hline - Base excess (mmol/L) & $-14,96 \pm 4,39$ & $-12,74 \pm 3,52$ & $0,04^{*}$ \\
\hline Kadar ureum hari ke 4 (mg/dL, rerata, SB) & $26,69 \pm 11,8$ & $27,06 \pm 12,9$ & $0,14^{*}$ \\
\hline Kadar kreatinin hari ke 4 (mg/dL) & $1,09 \pm 0,5$ & $0,89 \pm 0,5$ & $0,03^{\S}$ \\
\hline
\end{tabular}

*Uji Mann-Whitney $\quad{ }^{\star}$ Uji Chi-square $\quad{ }^{¥}$ Uji Kolmogorov-Smirnov $\quad{ }^{\S}$ Uji $t$-tidak berpasangan 


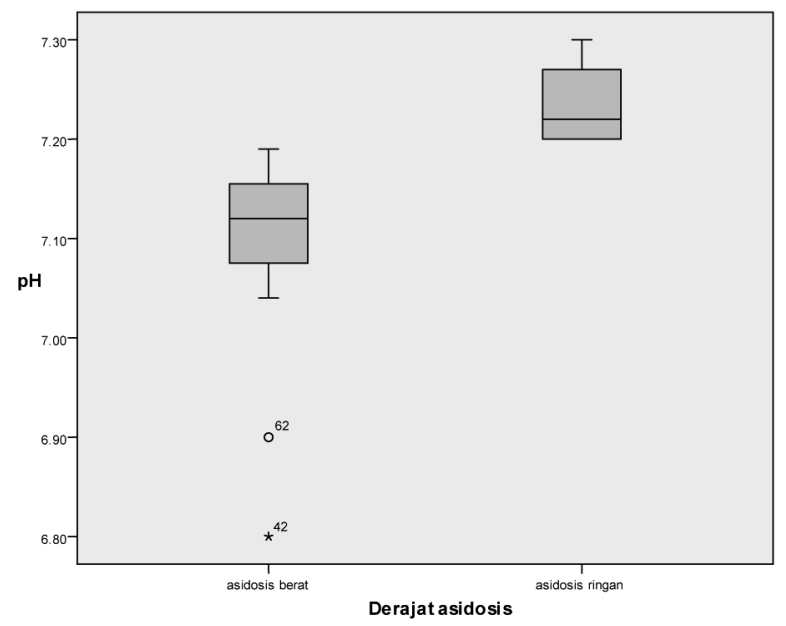

Gambar 1. Kadar $\mathrm{pH}$ hubungan derajat asidosis dengan kadar ureum dan kreatinin bayi asfiksia

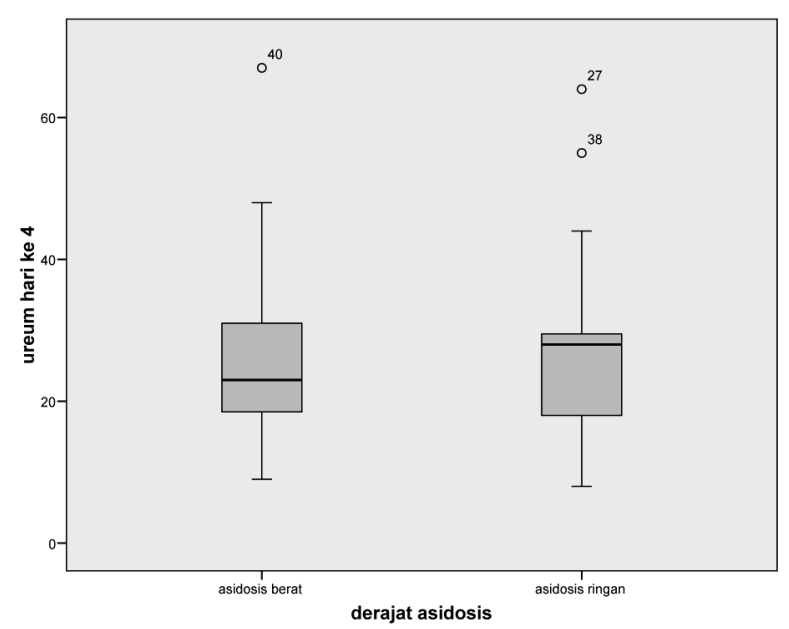

Gambar 2. Kadar ureum hari keempat hubungan derajat asidosis dengan kadar ureum dan kreatinin bayi asfiksia

Tampak distribusi data yang tidak normal pada kelompok asidosis berat karena didapatkan adanya satu sampel dengan nilai outlayer dan satu sampel dengan nilai ekstrim ( $\mathrm{pH} 6,8)$.

Tidak terdapat perbedaan kadar ureum pada hari keempat antara kelompok asidosis berat dan sedang (Tabel 1). Gambar 2 menunjukkan nilai kadar ureum pada pemeriksaan hari keempat antara kedua kelompok dalam rentang yang tidak jauh berbeda. Dari kedua kelompok didapatkan adanya nilai outlayer karena distribusi data yang tidak normal.

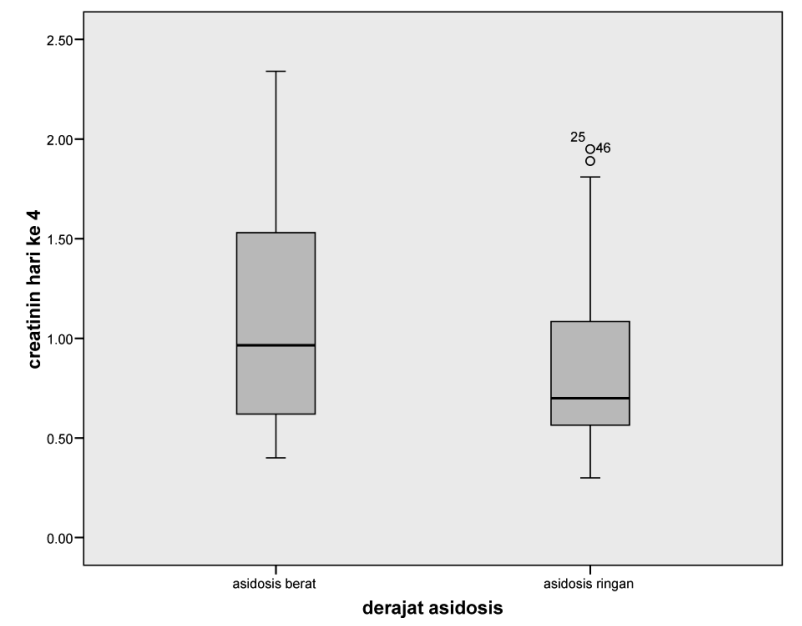

Gambar 3. Kadar kreatinin hari keempat hubungan derajat asidosis dengan kadar ureum dan kreatinin bayi asfiksia

Tabel 2. Hubungan derajat asidosis dengan peningkatan kadar ureum hari keempat

\begin{tabular}{lccc}
\hline \multirow{2}{*}{ Asidosis } & \multicolumn{2}{c}{ Ureum, $\mathrm{n}(\%)$} & \multirow{2}{*}{$p$} \\
\cline { 2 - 3 } & Meningkat & Normal & \\
\hline Berat & $20(62,5)$ & $12(37,5)$ & $0,87^{\ddagger}$ \\
Ringan & $20(64,5)$ & $11(35,5)$ & \\
\hline
\end{tabular}

${ }^{\sharp} \mathrm{Uji}$ Chi-square

Tabel 3. Hubungan derajat asidosis dengan peningkatan kadar kreatinin hari keempat

\begin{tabular}{lccc}
\hline \multirow{2}{*}{ Asidosis } & \multicolumn{2}{c}{ Kreatinin, $\mathrm{n}(\%)$} & \multirow{2}{*}{$p$} \\
\cline { 2 - 3 } & Meningkat & Normal & \\
\hline Berat & $16(50)$ & $16(50)$ & $0,08^{\mp}$ \\
Ringan & $9(29)$ & $22(71)$ & \\
\hline
\end{tabular}

${ }^{*} \mathrm{Uji}$ Chi-square

Kadar kreatinin hari keempat pada kelompok asidosis berat lebih tinggi dibandingkan kelompok asidosis ringan, bermakna secara statistik. Gambar 3 menunjukkan nilai kadar kreatinin pada pemeriksaan hari keempat antara kedua kelompok dalam rentang yang berbeda dan distribusi antara kedua kelompok masih dalam batas normal walaupun terdapat nilai outlayer pada kelompok asidosis ringan.

Di antara 63 neonatus dengan asfiksia didapatkan 20 neonatus dengan asidosis berat (62,5\%) dan 20 neonatus dengan asidosis ringan $(64,5 \%)$ mengalami 
peningkatan kadar ureum pada pemeriksaan hari keempat. Dari perhitungan statistik didapatkan derajat asidosis tidak berhubungan dengan peningkatan kadar ureum pada pemeriksaan hari keempat.

Di antara 63 neonatus dengan asfiksia didapatkan bahwa neonatus dengan asidosis berat $50 \%$ mengalami peningkatan kadar kreatinin pada hari keempat, sedangkan pada kelompok asidosis ringan sebagian besar (71\%) tidak mengalami peningkatan kadar kreatinin. Dari perhitungan statistik didapatkan derajat asidosis tidak berhubungan dengan peningkatan kadar kreatinin pada pemeriksaan hari keempat.

\section{Pembahasan}

Karakteristik subyek penelitian berdasarkan berat lahir dan jenis kelamin tidak didapatkan perbedaan bermakna antara kedua kelompok. Hal ini sesuai dengan penelitian oleh Gupta $\mathrm{dkk}^{12}$ dengan perbedaan pada penelitian tersebut menggunakan metode case control dan kelompok kasus dan kontrol yang digunakan yaitu bayi asfiksia dan bayi sehat. Berat lahir tidak mempengaruhi hasil pemeriksaan ureum dan kreatinin karena bayi cukup bulan mempunyai ginjal secara anatomis dan fungsional sudah berfungsi sempurna saat kehamilan trimester kedua.

Kadar $\mathrm{pH}$ dan base excess berbeda bermakna antara kelompok asidosis berat dan ringan. Rerata kadar $\mathrm{pH}$ dan base excess lebih rendah pada kelompok asidosis berat; sesuai dengan penelitian oleh Carlowicz $\mathrm{dkk}^{7} \mathrm{dan}$ Hankins dkk. ${ }^{13}$ Dikatakan bahwa parameter kadar $\mathrm{pH}$ dan base excess merupakan faktor prediktif terjadinya gangguan fungsi organ pada neonatus salah satunya adalah ginjal.

Derajat asidosis dinilai dari kadar $\mathrm{pH}$ dan base excess. Pada kadar $\mathrm{pH}$ dan base excess yang rendah, keadaan asidosis metabolik yang terjadi semakin berat. Parameter penentuan derajat asidosis disesuaikan dengan penelitian Wiberg ${ }^{11}$ yang mendapatkan batas kadar $\mathrm{pH}$ 7,2 sebagai batasan antara asidosis ringan dan berat. Asidosis metabolik yang berat mengakibatkan penurunan aliran darah ke ginjal yang berlanjut pada penurunan volume efektif darah di ginjal berakibat akan terjadi nekrosis tubular dan penurunan fungsi ginjal.

Hasil pemeriksaan kadar ureum tidak berbeda antara dua kelompok sedangkan kadar kreatinin tampak berbeda; namun tidak sesuai dengan hasil penelitian Wiberg. ${ }^{11}$ Perbedaan tersebut kemungkinan disebabkan karena perbedaan pada hari pengambilan spesimen untuk pemeriksaan kadar ureum dan kreatinin. Wiberg mengambil spesimen ureum dan kreatinin pada usia satu hari sehingga didapatkan rerata kadar ureum yang lebih tinggi (asidosis ringan $32,0 \pm 7,7 \mathrm{mg} / \mathrm{dL}$; asfiksia berat $42,1 \pm 4,4 \mathrm{mg} / \mathrm{dL}$ ) yang kemungkinan disebabkan masih ada pengaruh ureum dari ibu.

Kami mendapatkan derajat asidosis tidak mempunyai hubungan dengan peningkatan kadar ureum dan kreatinin pada pemeriksaan hari keempat. Hal tersebut juga tidak sesuai dengan penelitian Wibeg ${ }^{11}$ yang menemukan terdapat hubungan antara derajat asidosis dengan peningkatan kadar ureum dan kreatinin, yaitu makin berat derajat asidosis akan mengakibatkan peningkatan kadar ureum dan kreatinin. Perbedaan dengan penelitian Wiberg yaitu pengambilan sampel dilakukan pada hari pertama, sehingga sulit dilakukan generalisasi karena masih adanya pengaruh ureum dan kreatinin ibu.

Secara fisiologis suplai darah ke daerah juksta medular lebih banyak dibandingkan korteks, padahal volume korteks tiga kali lebih besar dibandingkan medula dan secara mikroskopis membran basal glomerolus bayi tipis dan belum berkembang sempurna. Kondisi yang tidak menguntungkan tersebut menyebabkan fungsi ginjal pada bayi lebih mudah terganggu terutama pada keadaan stres seperti akibat keadaan hipoksia yang dapat mempengaruhi proses metabolisme dan homeostasis. Makin berat keadaan hipoksia dan derajat asidosis akan makin meningkatkan risiko terjadi kerusakan anatomis dan gangguan fisiologis pada ginjal. Gangguan fungsi ginjal pada tahap dini bersifat ringan dengan gejala azotemia prerenal yaitu kenaikan kadar kreatinin dan ureum serum akibat hipoperfusi di daerah korteks. Tahap selanjutnya gangguan bersifat sedang yang disebabkan hipoperfusi di daerah medula. Jika keadaan tersebut berlangsung lama maka akan terjadi gangguan fungsi ginjal berat yaitu terjadinya perubahan struktur ginjal berupa nekrosis di tubulus atau korteks. ${ }^{14}$ Disimpulkan derajat asidosis tidak berhubungan dengan peningkatan kadar ureum dan kreatinin pada neonatus usia empat hari.

\section{Daftar pustaka}

1. Sabrine N, Singh J, Sinha SK. Medical management of birth asphyxia. Indian Pediatr 1999;36:369-76. 
2. Pramanik A. Respiratory distress syndrome. E Medicine J 2001;2. Didapat dari: http://www.emedicine.com/ped/ topic149.htm.

3. Marenstein GB. Predicting neonatal morbidity after perinatal asphyxia: a scoring system. Am J Obstet Gynecol 1990;162:174-82.

4. Polito C, Papale MR, La Manna A. Long term prognosis of acute renal failure in the full term neonate. Clin Pediatr (Phila) 1998;37:381-5.

5. Mohan PV, Pai PM. Renal insult in asphyxia neonatorum. Indian Pediatr 2000;37:1102-6.

6. Guignard YP, Torrado A, Mazouni SM, Gauntier E. Renal function in respiratory distress syndrome. J Pediatr 1976; 88:845-5.

7. Carlowicz GM, Adelman RD. Nonoliguric and oliguric renal failure in asphyxiated term neonate. Pediatr Nephrol 1995;9:718-22.

8. Prakash J, Kumar H, Kumar NS, Bhatia BD. Neonatal acute renal failure. A hospital based study. Indian J Nephrol 2000;10. Didapat dari: http//www.ijnephrol.com.

9. Chair I. Resusitasi pada bayi baru lahir. Dalam: Marwoto BW, Widodo E, Kamarul I. penyunting.
Penanganan gangguan nafas pada neonatus. Forum Ilmiah Tahunan V RSAB Harapan Kita. Jakarta: 1992.h.17-25.

10. American Heart Association and American Academy of Pediatrics. Textbook of neonatal resuscitation. Kattwinkel J, penyunting. Edisi ke-5. New York: McGraw-Hill; 2006.h. 1-14.

11. Wiberg-Itzel E, C Lipponer, M Norman, A Herbst, D Prebensen, A Hansson. Determination of $\mathrm{pH}$ or lactate in fetal scalp blood in management of intrapartum fetal distress: randomised controlled multicentre trial. BMJ 2008;336:1284-7.

12. Gupta BD, Sharma P, Bagla J, Parakh M, Soni JP. Renal failure in asphyxiated neonates. Indian Ped 2005;42:92834.

13. Hankins GD, Koen S, Gei AF, Lopez SM, Van Hook JW, Anderson GD. Neonatal organ system injury in acute birth asphyxia sufficient to result in neonatal encephalopathy. Obstet Gynecol 2002;99:688-91.

14. Umboh A. Hubungan asfiksia neonatorum dengan gangguan fungsi ginjal pada bayi baru lahir. Sari Pediatri 2002;4:50-3. 